\title{
FATTY ACID SYNTHESIS FROM ACETATE BY HUMAN LIVER HOMOGENATE FRACTIONS *
}

\author{
By W. BORTZ, $†$ S. ABRAHAM, I. L. CHAIKOFF AND W. E. DOZIER
}

(From the Department of Physiology, University of California, Berkeley, Calif.)

(Submitted for publication September 21, 1961 ; accepted December 14, 1961)

Evidence obtained during the last few years has shown that fatty acid synthesis in a variety of mammalian tissues $(1-4)$ as well as in yeast $(5,6)$ and bacteria $(7,8)$ is not simply the reverse of fatty acid oxidation. This is borne out by the finding that oxidative processes seem to be confined to the mitochondrial portion of the cell, whereas fatty acid synthesis apparently occurs in extramitochondrial compartments. ${ }^{1}$ The dependence of the synthetic mechanism upon formation and participation of malonyl-CoA and $\mathrm{TPNH}$ provides further evidence for separate synthetic and oxidative pathways $(3,6,10)$.

Recent reports from this laboratory have dealt with fatty acid synthesis from acetate in fractions prepared from homogenates of rat liver $(11,12)$. It was shown that the stimulation of fatty acid synthesis by addition of citrate far exceeded that obtained by addition of glucose-6-phosphate, even though the TPNH generated from these two compounds was of the same order (13). This finding, which indicates that citrate oxidation stimulates lipogenesis by a mechanism other than, and in addition to, that involving TPNH generation, offers no support for the view that TPNH generation (14) via the hexose monophosphate oxidative pathway limits lipogenesis from acetate in rat liver. Another outcome of these earlier studies was the demonstration that microsomes, although themselves unable to convert acetate to fatty acids, possess the capacity to stimulate lipo-

* Aided by grants from the U. S. Public Health Service, the Life Insurance Medical Research Fund, and the Alameda County Heart Association.

$\dagger$ Postdoctoral Fellow of the Life Insurance Medical Research Foundation.

1 Wakil, McLain and Warshaw (9) have reported synthesis of fatty acids from acetyl-CoA in a system isolated from pigeon and rat liver mitochondria. Since bicarbonate was not required for this synthesis, it would appear that fatty acid formation in mitochondria proceeds along a pathway that differs from that in extramitochondrial compartments of the cell. genesis by the particle-free, supernatant fraction of rat liver (15).

The conversion of acetate to fatty acids has been studied in normal human subjects by Lipsky, Haavik, Hopper and McDivitt (16) and in diabetic human subjects by Hennes and Shreeve (17) and Hennes and Redding (18). These investigations were confined to measurements of $\mathrm{C}^{14}$-fatty acids in plasma after the administration of $\mathrm{C}^{14}$-labeled acetate. Lipogenesis has also been demonstrated in several isolated human tissues, such as placenta (19) and aorta (20). However, most of the details on the mechanism of fatty acid synthesis have been obtained from studies with liver homogenates prepared from lower animals : rat (11), pigeon (3), pig (21), and chicken (22). In order to study the pathway of fatty acid synthesis in a human tissue, we used biopsy specimens of human liver. Experiments were also carried out with rat liver to provide a reference system uncomplicated by pathological states.

\section{EXPERIMENTAL}

\section{Patients and their treatment}

Pertinent information on the 10 human subjects from whom liver biopsies were obtained is recorded in Table I. With the exception of GB, who was at the University of California Hospital, San Francisco, all patients were operated at the San Francisco General Hospital.

The last oral feeding was given about $\mathbf{1 5}$ hours before surgery. Preoperative medications included meperidine, atropine, and a barbiturate. The anesthetic was nitrous oxide-oxygen. Liver biopsies were taken immediately after opening of the abdominal cavity and before the definitive surgery. The amounts of liver excised varied from 2 to $6 \mathrm{~g}$.

The rats used in this study were males of the LongEvans strain, weighing from 250 to $300 \mathrm{~g}$, which had been raised on an adequate stock diet (Diablo Labration).

The excised liver samples were placed in chilled beakers. In the case of 5 human and 4 rat livers, $250 \mathrm{mg}$ of slices were first prepared and the remainder was then weighed and minced. All other livers were minced directly. 
TABLE I

Observations on patients from whom liver biopsy samples were taken

\begin{tabular}{|c|c|c|c|c|c|c|}
\hline \multirow[b]{2}{*}{ Patient } & \multirow[b]{2}{*}{ Age } & \multirow[b]{2}{*}{ Sex } & \multirow{2}{*}{$\begin{array}{l}\text { Nutritional } \\
\text { status }\end{array}$} & \multirow[b]{2}{*}{ Clinical diagnosis } & \multicolumn{2}{|r|}{ Liver } \\
\hline & & & & & Function tests* & Histology \\
\hline $\mathrm{GB} \dagger$ & 72 & $\%$ & Normal & Islet cell adenoma & $\begin{array}{l}\text { BSP } 4 \% ; \text { A/G } 3.9 / 3.0 \\
\text { g \%; alk. pase. } 5.0 \mathrm{U} ; \\
\text { prothrombin time } 81 \%\end{array}$ & $\begin{array}{l}\text { Unremarkable portal areas, hepatic } \\
\text { cords, and central veins; hepatic cells } \\
\text { contained considerable glycogen }\end{array}$ \\
\hline JB & 53 & $\sigma^{7}$ & $\begin{array}{l}\text { Poor, chronic } \\
\text { alcoholic }\end{array}$ & Duodenal ulcer & $\begin{array}{l}\text { BSP } 4 \% ; \text { A/G } 2.6 / 2.8 \\
\text { g } \% ; \text { II } 4.0\end{array}$ & $\begin{array}{l}\text { Slight increase in connective tissue in } \\
\text { portal areas; hepatic cells normal }\end{array}$ \\
\hline $\mathbf{R} \mathbf{R}$ & 70 & \% & $\begin{array}{l}\text { Obese, but recent } \\
\text { weight loss }\end{array}$ & $\begin{array}{l}\text { Carcinoma of the } \\
\text { stomach }\end{array}$ & $\begin{array}{l}\text { BSP } 15 \% \text {; CF negative; } \\
\text { A/G } 3.1 / 4.4 \mathrm{~g} \%\end{array}$ & $\begin{array}{l}\text { Periportal proliferation of fibrous con- } \\
\text { nective tissue; bile duct proliferation; } \\
\text { hepatic cells unremarkable }\end{array}$ \\
\hline SA & 58 & \% & Moderately obese & $\begin{array}{l}\text { Cholelithiasis and } \\
\text { chronic cholecystitis }\end{array}$ & $\begin{array}{l}\text { BSP 13\%; A/G 3.6/4.0 } \\
\text { g \%; TT } 3 \text { U; alk. pase. } \\
8.1 \text { U }\end{array}$ & Modest focal fatty change \\
\hline TC & 23 & \% & Normal & $\begin{array}{l}\text { Cholelithiasis and } \\
\text { chronic cholecystitis }\end{array}$ & $\begin{array}{l}\text { BSP } 4 \% \text {; TT } 3 \text { U; alk. } \\
\text { pase. } 3.8 \mathrm{U} \text {; total bili- } \\
\text { rubin } 0.6 \mathrm{mg} \% \text {; CF neg- } \\
\text { ative }\end{array}$ & Normal \\
\hline SH & 57 & $\sigma^{\top}$ & Undernourished & Duodenal ulcer & $\begin{array}{l}\text { BSP } 44 \% \text {; T } 1 \mathrm{U} ; \mathrm{A} / \mathrm{G} \\
3.0 / 3.2 \mathrm{~g} \% ; \text { total bili- } \\
\text { rubin } 1.4 \mathrm{mg} \% \text {; } \mathrm{CF} \\
2+; \text { alk. pase. } 3.0 \mathrm{U}\end{array}$ & $\begin{array}{l}\text { Portal fibrosis and inflammation; } \\
\text { focal collapse and hepatocellular } \\
\text { damage consistent with viral hepatitis }\end{array}$ \\
\hline MI† & 63 & $\%$ & $\begin{array}{l}\text { Obese, but recent } \\
\text { weight loss }\end{array}$ & $\begin{array}{l}\text { Carcinoma of the } \\
\text { gall bladder }\end{array}$ & $\begin{array}{l}\text { BSP } 25 \% ; \text { A/G } 2.5 / 4.9 \\
\text { g \% CF } 3+\text { TT } 5 \text { U; } \\
\text { alk. pase. } 8.2 \text { U }\end{array}$ & $\begin{array}{l}\text { Focal centrolobular congestion with } \\
\text { minimal increase in fibrous tissue in } \\
\text { portal areas }\end{array}$ \\
\hline $\mathrm{AK}$ & 74 & $\sigma^{\top}$ & $\begin{array}{l}\text { Normal, chronic } \\
\text { alcoholic }\end{array}$ & Chronic cholecystitis & $\begin{array}{l}\text { BSP } 8 \% ; \text { A/G } 3.0 / 4.0 \\
\text { g\%; II } 9.0 ; \text { total bil- } \\
\text { irubin } 2.8 \mathrm{mg} \% \text { \% TT } \\
1 \text { U; CF negative; alk. } \\
\text { pase. } 5.2 \mathrm{U}\end{array}$ & $\begin{array}{l}\text { Mild portal fibrosis, chronic peri- } \\
\text { cholangitis, or both }\end{array}$ \\
\hline $\mathrm{JT}$ & 38 & $\sigma^{\top}$ & $\begin{array}{l}\text { Normal, chronic } \\
\text { alcoholic }\end{array}$ & Chronic cholecystitis & $\begin{array}{l}\text { BSP } 36 \% ; \text { A /G } 4.0 / 4.1 \\
\text { g\%; alk. pase. } 5.6 \mathrm{U} ; \\
\text { II 9.0; TT } 1 \text { U; CF } \\
\text { negative }\end{array}$ & $\begin{array}{l}\text { Minimal fatty infiltration; hepatic } \\
\text { architecture otherwise unremarkable }\end{array}$ \\
\hline EB & 46 & $\sigma^{7}$ & $\begin{array}{l}\text { Normal, chronic } \\
\text { alcoholic }\end{array}$ & Duodenal ulcer & $\begin{array}{l}\text { BSP } 17 \% ; \text { A/G } 3.8 / 3.1 \\
\text { g \%; TT } 1 \text { U; CF nega- } \\
\text { tive; alk. pase. } 3.3 \text { U; } \\
\text { II } 6.0 ; \text { prothrombin } \\
\text { time } 73 \%\end{array}$ & Normal \\
\hline
\end{tabular}

* Abbreviations: BSP, sulfobromophthalein; A/G, albumin-globulin; alk. pase., alkaline phosphatase; II, icterus index; CF, cephalin flocculation; and TT, thymol turbidity.

T These patients received a glucose infusion the night before operation.

\section{Preparation and fractionation of homogenates}

The minced liver was homogenized with 3 vol of isotonic sucrose $(0.25 \mathrm{M})$ by three rapid strokes, in a motor-driven homogenizer of the Potter-Elvehjem type, with a Teflon pestle of $0.5 \mathrm{~mm}$ tolerance. Nuclei and cellular debris were removed by centrifugation at $800 \mathrm{G}^{2}$ for 15 minutes. Mitochondria were removed by centrifugation at $8,700 \mathrm{G}$ for 15 minutes in the Spinco model $\mathrm{L}$ ultracentrifuge. The microsomes were sedimented by additional centrifugation at $100,000 \mathrm{G}$ for 45 minutes, and the resultant clear supernatant fraction underlying a fatty layer was carefully removed with a pipet. $^{3}$ This supernatant fraction contained 11 to $18 \mathrm{mg}$ per $\mathrm{ml}$ (human liver) and 15 to $20 \mathrm{mg}$ per $\mathrm{ml}$ (rat liver) of soluble protein. The microsomal pellet was gently rehomogenized, by hand, in the tissue grinder described above, with $0.25 \mathrm{M}$ sucrose $(1 \mathrm{ml}$ per $\mathrm{g}$ of original wet weight

2 All values for centrifugal force are given as the average force in the center of the tube.

${ }^{3}$ Fatty acids added to medium as sodium palmitate or albumin palmitate inhibit fatty acid synthesis from acetate (Reference 23 and unpublished observations from this laboratory). liver). The microsomal suspension so prepared from both human and rat liver contained 33 to $60 \mathrm{mg}$ protein per $\mathrm{ml}$.

\section{Preparation of slices}

Slices approximately $0.4 \mathrm{~mm}$ thick were prepared with the McIlwain-Buddle tissue chopper (24). The slices were blotted on filter paper, and immediately thereafter 250-mg portions were incubated as described below. All preparative procedures were carried out in a cold room maintained at 2 to $4^{\circ} \mathrm{C}$.

\section{Incubation procedures}

Homogenate experiments. All incubations were begun within 3 hours after the tissues were excised. The experiment was initiated by delivery of $0.4 \mathrm{ml}$ of the particle-free supernatant fraction and varying amounts of the microsomal suspension into tubes which contained $0.5 \mathrm{ml}$ of the incubation medium. This incubation medium contained, except where otherwise noted, $60 \mu$ moles of glycylglycine- $\mathrm{KOH}$ buffer at $\mathrm{pH} 7.5,15 \mu$ moles of reduced glutathione ( $\mathrm{K}^{+}$salt), $18 \mu$ moles of $\mathrm{MgCl}_{2}, 0.25$ $\mu$ mole of $\mathrm{MnCl}_{2}, 2.5 \mu$ moles of $\mathrm{KHCO}_{3}, 1.25 \mu$ moles of potassium acetate-1- $\mathrm{C}^{14}\left(2.5 \times 10^{5} \mathrm{cpm}\right), 12 \mu$ moles of 
ATP ( $\mathrm{K}^{+}$salt), $0.03 \mu$ mole of CoA, $0.125 \mu$ mole of TPN, and $18.8 \mu$ moles of potassium citrate. Air was the gas phase. The incubation was conducted with mechanical agitation, at $37^{\circ} \mathrm{C}$, and was terminated at the end of 2 hours by addition of $1 \mathrm{ml}$ of a 30 per cent $\mathrm{KOH}$ solution.

Slice expcriments. The slices were incubated for 2 hours with $2 \mathrm{ml}$ of Krebs-Henseleit bicarbonate buffer ( $\mathrm{pH} 7.3$ to 7.4 ) containing $2.5 \mu$ moles potassium acetate$1-\mathrm{C}^{14}\left(5 \times 10^{5} \mathrm{cpm}\right)$, with mechanical agitation, at $37^{\circ} \mathrm{C}$. The gas phase was 95 per cent $\mathrm{O}_{2 .}$ and 5 per cent $\mathrm{CO}_{2}$. The centerwell flasks used for the incubation have been described (25).

Substrates and cofactors. Acetate-1- $\mathrm{C}^{\mathbf{1 4}}$ was prepared, by the conventional Grignard reaction, from $\mathrm{C}^{14} \mathrm{O}_{2}$ and methylmagnesium iodide, and isolated as the potassium salt (26). Coenzyme A, TPN, and ATP were obtained from Pabst Laboratories; disodium glucose-6-phosphate, $\alpha$-keto-glutarate, and cis-aconitate from the California Corporation for Biochemical Research; $d, l$-isocitric acid lactone and isocitric dehydrogenase from Sigma Chemical Company; glycylglycine, avidin, and D-biotin from $\mathrm{Nu}$ tritional Biochemical Corporation; reduced glutathione from Schwarz Laboratories; and glucose-6-phosphate dehydrogenase from C. F. Boehringer and Sons, Germany. Monopotassium salt of $\mathbf{L}_{\mathbf{3}}(+)$-isocitric acid was isolated from Bryophyllum calycinum (27).

$d, l$-Isocitric lactone was converted to the salt with $\mathrm{KOH}$, and neutralized with $\mathrm{HCl}$ before use (28). The $\mathrm{L}_{\mathbf{s}}(+)$-isocitrate was also converted to the tripotassium salt before being added to the medium.

\section{Analytical procedures}

$\mathrm{C}^{14} \mathrm{O}_{2}$ assay. One minute before termination of the slice experiments, $0.5 \mathrm{ml}$ of a solution containing 1 vol of $1 \mathrm{M}$ Hyamine ${ }^{4}$ hydroxide in methyl alcohol and 3 vol of toluene was injected through the rubber serum cap into the center well of the incubation flask. Enzymatic reactions were stopped by injection of $0.5 \mathrm{ml}$ of a $6 \mathrm{~N}$ $\mathrm{H}_{3} \mathrm{PO}_{4}$ solution into the main compartment of the vessel containing the slices and incubation medium. The flask was then mechanically agitated at room temperature for 30 minutes to insure complete absorption of the respiratory $\mathrm{CO}_{2}$ by the Hyamine mixture in the center well. The recovery of $\mathrm{C}^{14} \mathrm{O}_{2}$ from a $\mathrm{C}^{14}$-bicarbonate solution was quantitative with this technique.

The Hyamine- $\mathrm{C}^{14} \mathrm{O}_{2}$ mixture and the toluene washes were quantitatively transferred by suction to a scintillation vial, $48 \mathrm{mg}$ of 2,5-phenyloxazole (PPO) was added, and the volume in the vials was made up to $20 \mathrm{ml}$ with toluene. The $\mathrm{C}^{14} \mathrm{O}_{2}$ was assayed in a Packard automatic Tri-Carb liquid scintillation spectrometer to within \pm 3 per cent. Control experiments showed that the amount of methanol present in these samples produced a 10 per cent quenching effect when compared with samples counted in pure toluene solution.

${ }^{4}$ Hyamine-10X is the trade name for para-diisobutyl cresoxy ethoxy ethyl dimethyl benzyl ammonium hydroxide, purchased from the Rohm and Haas Company.
$C^{14}$-fatty acid assay. The slices contained in the main compartment of the center-well flask were washed with copious amounts of water, and the washed slices were saponified overnight with $2 \mathrm{ml}$ of 30 per cent $\mathrm{KOH}$, in a tube under reflux. The saponification mixture was chilled in an ice bath, $5 \mathrm{ml}$ of hexane was then added, and the mixture was acidified with $2 \mathrm{ml}$ of concentrated $\mathrm{HCl}$. The tube was closed with a rubber stopper, and the entire contents vigorously shaken. The two phases were separated by centrifugation, and the hexane layer was removed with a pipet. This hexane extraction was repeated, and the two extracts were combined. One-ml aliquots from the $10 \mathrm{ml}$ of hexane solution were assayed for $\mathrm{C}^{14}$ activity with $24 \mathrm{mg}$ of $\mathrm{PPO}$ in $10 \mathrm{ml}$ of toluene, as described above. No quenching by this amount of hexane was observed.

The $\mathrm{C}^{14}$-fatty acids produced in the homogenate experiments were isolated and assayed as previously described (29). The complete extraction of the $\mathrm{C}^{14}$-fatty acids from these mixtures has been demonstrated in a previous report from this laboratory (29).

Assay for nonsaponifiable $C^{14}$. Cholesterol from the slice experiments was isolated as the digitonide (30) without the addition of carrier, dissolved in methanol, and assayed for $\mathrm{C}^{14}$ as described above. The isolation of the nonsaponifiable fraction from hexane extracts in the homogenate experiments and the assay of its $\mathrm{C}^{16}$ activity have been described (29).

Aliquots of the incubation media were oxidized in center-well flasks by the persulfate combustion method (31), and the $\mathrm{C}^{14} \mathrm{O}_{2}$ was trapped in a $\mathrm{KOH}$ solution. The potassium hydroxide-bicarbonate solution was transferred to other center-well flasks and acidified at room temperature. The $\mathrm{C}^{14} \mathrm{O}_{2}$ evolved was trapped in the Hyamine-methanol-toluene solution, and was assayed for $\mathrm{C}^{16}$ activity as described above. This procedure provided an accurate determination of the $\mathrm{C}^{14}$ activity in the incubation medium at the start of the experiment.

Protein was determined by the biuret method described by Gornall, Bardawill and David (32).

\section{RESULTS}

Conversion of the $\mathrm{C}^{14}$ of acetate-1- $\mathrm{C}^{14}$ to fatty acids ${ }^{5}$ was studied in both slice and homogenate fractions prepared from each of five human and four rat livers (Table II). An experiment with a human and a rat liver was performed at the same time. Fatty acid synthesis per milligram of supernatant protein in the composite system (supernatant plus microsomes) was 3 to 4 times higher than that observed with slices. (We have assumed that $250 \mathrm{mg}$ of slices is equivalent to 0.75

5 The fatty acids synthesized from acetate by the human livers studied here were analyzed by gas chromatographic techniques and found to be predominantly myristic and palmitic. Smaller amounts of lauric, stearic, and other longer chain acids were also present. 


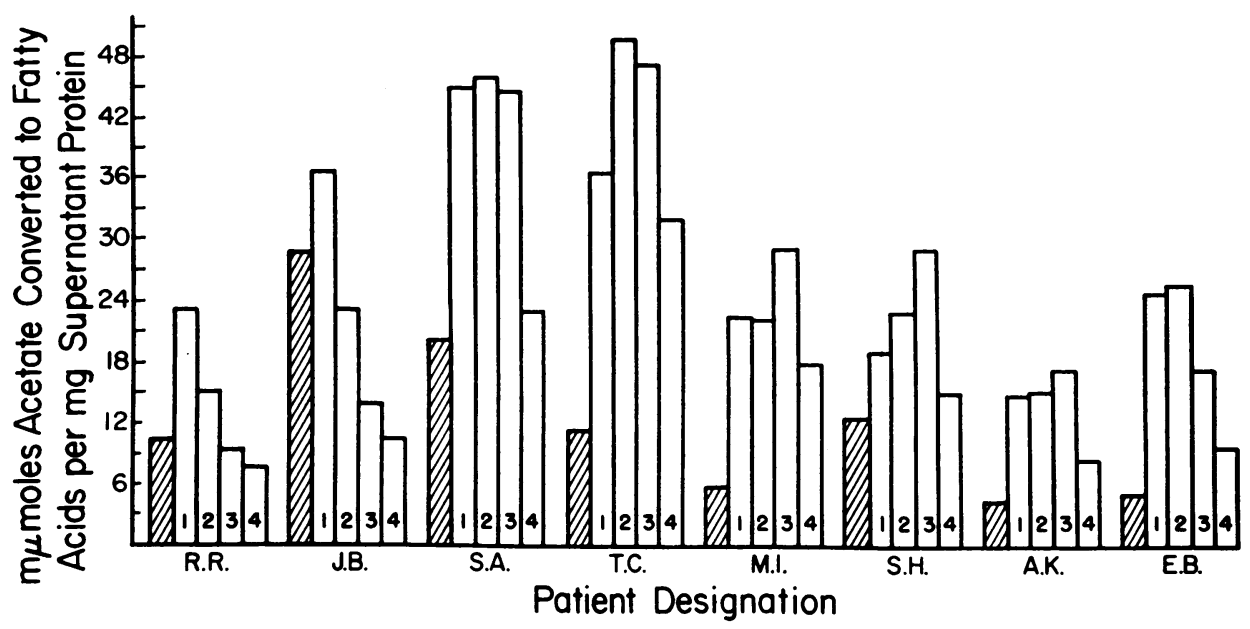

Fig. 1. EFfect of addition of varying amounts of a microsomal suspension to the PARTIClE-FREE SUPERNATANT FRACTION, BOTH PREPARED FROM THE SAME HUMAN LIVERS, ON FATTY ACID SYNTHESIS FROM ACETATE. $\mathbb{Z}=$ particle-free supernatant fraction alone; $1=0.025$ $\mathrm{ml}$ of microsomal suspension added to the particle-free supernatant fraction; $2=0.05 \mathrm{ml}$ of microsomal suspension added; $3=0.10 \mathrm{ml}$ of microsomal suspension added; $4=0.30 \mathrm{ml}$ of microsomal suspension added.

TABLE II

Comparison of fatty acid synthesis from acetate-1-C $C^{14}$ by liver slices and by homogenate fractions*

\begin{tabular}{lcc}
\hline \multicolumn{1}{c}{ Liver preparation } & Human [5]† & Rat [4] \\
\hline Slice & $7.3 \pm 4.0$ & $6.3 \pm 2.6$ \\
Supernatant & $8.1 \pm 4.1$ & $12.3 \pm 3.9$ \\
Mitochondria & 0 & 0 \\
Microsomes & 0 & 0 \\
Supernatant + microsomes & $23.1 \pm 3.1$ & $24.0 \pm 5.8$
\end{tabular}

* Experimental conditions are described in the text. Values recorded are averages and their standard errors, and are expressed as $m \mu$ moles of acetate- $1-C^{14}$ converted to fatty acids per $\mathrm{mg}$ protein contained in the particle-free supernatant fraction. In order to compare fatty acid synthesis in the slice and homogenate system, it was assumed that the volume of supernatant solution obtained from $1 \mathrm{~g}$ of tissue was equal to the volume of homogenizing solution $(3 \mathrm{ml})$. One $\mathrm{ml}$ of the particle-free supernatant fraction contained about $15 \mathrm{mg}$ of protein. Thus, 250 $\mathrm{mg}$ of slices would be equivalent to $0.75 \mathrm{ml}$ of the particlefree supernatant fraction containing about $12 \mathrm{mg}$ of soluble protein. The figures in brackets give the number of experiments with different livers.

$\dagger$ Liver from Patients SH, MI, AK, JT, and EB.

$\mathrm{ml}$ of the particle-free supernatant fraction.) The higher synthesis of fatty acids from acetate by the homogenate fractions might reflect the fact that oxidizing enzymes present in the slice were removed from the homogenate system, thus permitting a more efficient utilization of acetyl-CoA for fatty acid synthesis.

Although the particles (microsomes or mitochondria) alone are not capable of converting acetate to fatty acids (11), the addition of microsomes to the particle-free supernatant fraction augmented the amount of $\mathrm{C}^{14}$-fatty acid synthesis observed with the supernatant fraction alone (Table II). In general, the addition of mitochondria depressed the synthesis.

The results of experiments in which varying amounts of microsomal protein were added to the particle-free supernatants obtained from human and rat liver homogenates are shown in Figures 1 and 2. Since the ratio of supernatant protein to microsomal protein required for max-

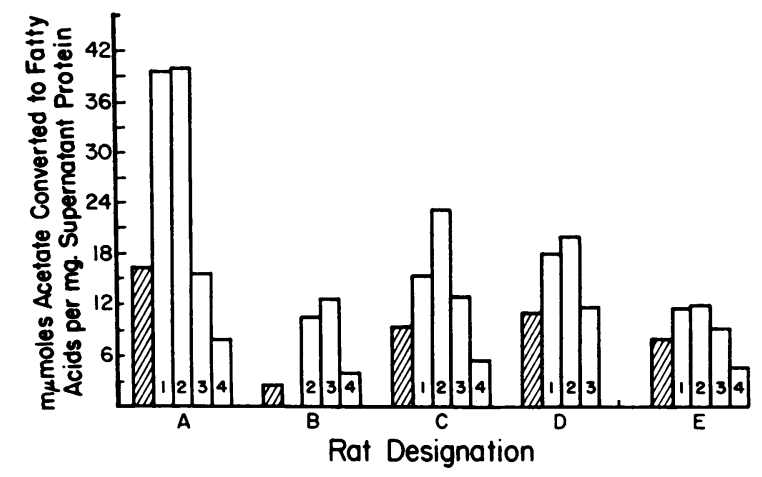

Fig. 2. EFFECT OF ADDItion of VARYing AMOUNTS of A MICROSOMAL SUSPENSION TO THE PARTICLE-FREE SUPERNATANT FRACTION, BOTH PREPARED FROM THE SAME RAT LIVER, ON FATTY ACID SYNTHESIS FROM ACETATE. For meaning of symbols see Figure 1. 
TABLE III

Effect of TPNH-generating substrates on fatty acid synthesis from acetate-1-C ${ }^{14}$ by supernatant and microsomal fractions obtained from homogenates of human and rat liver ${ }^{*}$

\begin{tabular}{|c|c|c|c|c|c|}
\hline \multirow[b]{2}{*}{ Liver } & \multicolumn{3}{|c|}{ Acetate converted to fatty acids in the presence of added: } & \multicolumn{2}{|c|}{ Ratio } \\
\hline & $\underset{\text { (A) }}{\text { Nonet }}$ & $\begin{array}{l}5 \mu \text { moles of } \\
\text { glucose-6- } \\
\text { phosphate } \neq \\
\text { (B) }\end{array}$ & $\begin{array}{l}18.8 \mu \text { moles of } \\
\text { citrate } \\
\text { (C) }\end{array}$ & $\mathrm{B} / \mathrm{A}$ & $\mathrm{C} / \mathrm{A}$ \\
\hline & mumoles & mumoles & mumoles & & \\
\hline Human & $1.5 \pm 0.11[8] \S$ & $1.7 \pm 0.32[8]$ & $26.1 \pm 1.2[9]$ & 1.1 & 17 \\
\hline Rat & $0.8 \pm 0.03[5]$ & $1.5 \pm 0.11[5]$ & $23.6 \pm 4.8[7]$ & 1.9 & 30 \\
\hline
\end{tabular}

* For experimental details see text. Microsomal levels that yielded maximum synthesis were used. Average values and their standard errors are given.

$\dagger$ No citrate was added to the medium.

F Glucose-6-phosphate was substituted for citrate in the medium.

$\$$ Number of experiments with different livers is given in brackets.

imum synthesis varied from preparation to preparation, such a concentration study was carried out in most experiments. In both human and rat liver homogenate experiments, microsomal stimulation was highest when about 0.025 to $0.10 \mathrm{ml}$ of the microsomal suspension was added to 0.4 $\mathrm{ml}$ of the supernatant fraction. Additional amounts of the microsomal suspension caused inhibition. It would appear that, when fatty acid synthesizing activity in the supernatant fraction is high, less of the microsomal suspension is required to stimulate maximum conversion of acetate to fatty acids. This suggests that occasionally there may be a release of microsomal protein into the supernatant fraction.

It has been established by many workers that TPNH is an essential cofactor for the synthesis of fatty acid by cell-free systems (1-3). Table III shows the results of experiments in which

\section{TABLE IV}

Effect of tricarboxylic acids on conversion of $C^{14}$ of acetate1-C $C^{14}$ to fatty acids by supernatant plus microsomal fractions obtained from human and rat liver homogenates *

\begin{tabular}{|c|c|c|c|c|c|}
\hline \multirow{2}{*}{\multicolumn{2}{|c|}{$\begin{array}{l}\text { Additions to incubation } \\
\text { medium }\end{array}$}} & \multicolumn{4}{|c|}{$\begin{array}{l}\text { Acetate converted to fatty } \\
\text { acids per mg supernatant } \\
\text { protein }\end{array}$} \\
\hline & & \multicolumn{2}{|c|}{ Experiment 1} & \multicolumn{2}{|c|}{ Experiment 2} \\
\hline \multirow[t]{2}{*}{ Compound } & Amount & $\mathrm{AK}$ & Rat & $\overline{\text { EB }}$ & Rat \\
\hline & umoles & $m_{\mu \nu}$ & oles & $m_{\mu}$ & oles \\
\hline $\begin{array}{l}\text { None (no citrate) } \\
\text { Glucose-6-phosphate } \\
\text { Citrate } \\
\text { cis-Aconitate } \\
\text { Ls (+)-isocitrate } \\
d, \text {-Isocitrate }\end{array}$ & $\begin{array}{c}5 \\
18.8 \\
18.8 \\
18.8 \\
18.8\end{array}$ & $\begin{array}{l}0.84 \\
0.84 \\
15.0 \\
11.4 \\
15.9 \\
19.7\end{array}$ & $\begin{array}{l}0.43 \\
0.73 \\
23.4 \\
19.8 \\
18.9 \\
15.1\end{array}$ & $\begin{array}{r}1.3 \\
1.4 \\
25.6 \\
14.7 \\
16.4 \\
14.2\end{array}$ & $\begin{array}{c}0.60 \\
0.80 \\
12.1 \\
10.3 \\
9.0 \\
8.4\end{array}$ \\
\hline
\end{tabular}

* For experimental details see text. Microsomal suspension (0.05 $\mathrm{ml}$ ) was added to each incubation mixture. $\dagger$ Each compound was used in place of citrate in the incubation
medium. either glucose-6-phosphate or citrate was used as the sole TPNH-generating substrate in experiments with human and rat liver homogenate fractions (supernatant plus microsomes). When neither glucose-6-phosphate nor citrate was added, there was little fatty acid synthesis. Although glucose-6-phosphate ${ }^{6}$ is capable of producing TPNH $(12,14)$, its addition did not stimulate lipogenesis to any appreciable degree. On the other hand, the addition of citrate to the incubation medium caused a pronounced increase in this synthesis. The last column of Table III shows that the stimulation by citrate was 17 -fold in the experiments with human liver and 30 -fold in those with the rat liver system.

The particle-free supernatant fractions from both human and rat liver homogenates contain aconitase in addition to isocitric dehydrogenase (unpublished observations). It therefore became of interest to test the stimulating effect of other tricarboxylic acids related to citrate. The data presented in Table IV show that cis-aconitate, $\mathrm{L}_{\mathbf{s}}(+)$-isocitrate, and $d, l$-isocitrate adequately fulfilled the citrate requirement for fatty acid synthesis in both human and rat liver homogenate fractions.

Because glucose-6-phosphate did not stimulate lipogenesis from acetate in human or rat liver systems, it might be concluded that the amount of glucose-6-phosphate dehydrogenase (G-6-PD) present in these systems was limiting the pro-

\footnotetext{
${ }^{6}$ Previous experiments with the rat liver system have shown that glucose-6-phosphate in concentrations from $8 \times 10^{-4}$ to $1.6 \times 10^{-2} \mathrm{M}$ will not stimulate fatty acid synthesis (11).
} 
TABLE V

Attempts to replace citrate requirement for fatty acid synthesis from acetate by the composite system (supernatant plus microsomes) prepared from human livers *

\begin{tabular}{|c|c|c|c|c|c|c|c|}
\hline \multirow[b]{2}{*}{ Expt. } & \multicolumn{6}{|c|}{ Additions to the incubation medium } & \multirow{2}{*}{$\begin{array}{l}\text { Fatty acid } \\
\text { synthesis } \\
\text { (expressed as } \\
\% \text { of citrate } \\
\text { effect) }\end{array}$} \\
\hline & $\begin{array}{l}\text { Glucose-6- } \\
\text { phosphate } \\
(5 \mu \text { moles })\end{array}$ & $\begin{array}{c}\text { Glucose-6- } \\
\text { phosphate } \\
\text { dehydrogenase }\end{array}$ & $\underset{(15 \mu \text { moles })}{\mathrm{KHCO}_{2}}$ & $\begin{array}{c}\alpha \text {-Ketoglu- } \\
\text { tarate (20 } \\
\mu \text { moles) }\end{array}$ & $\begin{array}{c}\text { Citrate } \\
(18.8 \mu \text { moles })\end{array}$ & $\begin{array}{l}\text { Isocitric de- } \\
\text { hydrogenase }\end{array}$ & \\
\hline$A$ & None & None & None & None & None & None & 4.5 \\
\hline $\mathrm{B}$ & + & None & None & None & None & None & 6.0 \\
\hline $\mathrm{C}$ & + & + & None & None & None & None & 8.3 \\
\hline $\mathrm{D}$ & + & + & + & None & None & None & 4.0 \\
\hline $\mathrm{E}$ & None & None & + & + & None & None & 17 \\
\hline $\mathrm{F}$ & + & + & + & + & None & None & 22 \\
\hline $\mathrm{G}$ & None & None & None & None & + & None & 100 \\
\hline $\mathrm{H}$ & + & None & None & None & + & None & 105 \\
\hline I & + & + & None & None & + & None & 105 \\
\hline $\mathrm{J}$ & + & + & None & None & + & + & 102 \\
\hline $\mathrm{J}$ & + & + & + & + & + & None & 81 \\
\hline
\end{tabular}

* The experiments were carried out with homogenate fractions prepared from the livers of Patients AK and EB. The assay system contained all substrates and cofactors described in Methods, with the exception of citrate. Additional compounds and purified enzymes were added as shown. ( + ) indicates addition to the incubation medium; 0.05 ml of microsomal suspension was added to each incubation mixture. The average $\mathrm{C}^{14}$-fatty acid recovery observed in the presence of citrate (experiment $G$ ) was arbitrarily assigned a value of 100 , and other results are shown in relation to that value.

† The amount of enzyme added will produce $13.8 \mathrm{~m} \mu$ moles TPNH/min with glucose-6-phosphate as substrate

$\ddagger$ The amount of enzyme added will produce $33.2 \mathrm{~m} \mu \mathrm{moles} \mathrm{TPNH} / \mathrm{min}$ with isocitrate as substrate.

duction of TPNH. However, when G-6-PD was added to the human liver homogenate composite system (supernatant plus microsomes) in amounts that will produce $1.7 \mu$ moles of $\mathrm{TPNH}^{\mathrm{i}}$ per 2 hour incubation period, there was no additional fatty acid synthesis from acetate-1- $\mathrm{C}^{14}$. (Compare experiments $\mathrm{B}$ and $\mathrm{C}$ in Table V.) The failure to observe stimulation with both glucose6-phosphate and G-6-PD suggests that this enzyme, which is concerned with TPNH production from hexose phosphate, is not limiting fatty acid synthesis in the human liver system.

Similarly, if the activity of enzymes concerned with citrate oxidation and TPNH generation were limiting, we might expect increased fatty acid synthesis by addition of isocitric dehydrogenase to the system. But experiment $\mathrm{J}$ of Table $\mathrm{V}$ shows that the addition of isocitric dehydrogenase (in amounts that will produce 4.0 $\mu$ moles of TPNH in 2 hours) did not increase synthesis of fatty acids from acetate over that observed in the absence of added enzyme (experiment G).

Since tricarboxylic acids (isocitrate and cisaconitate) other than citrate augmented fatty acid yields from acetate, experiments were carried out

\footnotetext{
7 The extinction coefficient of TPNH at $340 \mathrm{~m} \mu$ is
} $6.22 \times 10^{\circ} \mathrm{cm}^{2}$ per mole (33). in which the dicarboxylic acid product of the isocitric dehydrogenase reaction, namely, $\alpha$-ketoglutarate, was substituted for citrate. Experiments $\mathrm{E}$ and $\mathrm{F}$ in Table $\mathrm{V}$ show that the extent of synthesis observed with $\alpha$-ketoglutarate was somewhat higher than that observed in the absence of $\alpha$-ketoglutarate or in the presence of glucose-6-phosphate. But the extent of synthesis with $\alpha$-ketoglutarate did not approach that observed when citrate was added to the system. The data in Tables IV and $\mathrm{V}$ emphasize that

TABLE VI

Effect of avidin and $\mathrm{D}-$ biotin on conversion of $C^{14}$ of acetate1-C ${ }^{14}$ to fatty acids by human and rat liver homogenates *

\begin{tabular}{|c|c|c|c|}
\hline \multirow[b]{2}{*}{ Liver } & \multicolumn{3}{|c|}{$\begin{array}{l}\text { Acetate converted to fatty acids } \\
\text { per mg supernatant protein }\end{array}$} \\
\hline & $\begin{array}{l}\text { No } \\
\text { addition }\end{array}$ & $\begin{array}{l}\text { Avidin } \\
(0.2 \mathrm{mg})\end{array}$ & $\begin{array}{c}\text { Avidin } \\
(0.2 \mathrm{mg}) \\
+ \\
\text { D-biotin } \\
(0.05 \mathrm{mg})\end{array}$ \\
\hline & \multicolumn{2}{|c|}{$m \mu m o l e s$} & mumoles \\
\hline Rat & 40.3 & 2.6 & 37.2 \\
\hline Rat & 40.4 & 0.8 & 40.4 \\
\hline Human (RR) & 23.0 & 2.4 & 21.0 \\
\hline Human (JB) & 39.6 & 1.7 & 22.0 \\
\hline Human (MI) & 29.4 & 0.8 & 23.4 \\
\hline Human (SH) & 29.0 & 1.2 & 27.7 \\
\hline
\end{tabular}

* For experimental details see text. Microsomal suspension $(0.05 \mathrm{ml})$ was added to each incubation mixture. 
TABLE VII

Effect of changing incubation conditions on conversion of $C^{14}$ of acetate-1-C ${ }^{14}$ to fatty acids by supernatant plus microsomal fractions obtained from human and rat liver homogenates*

\begin{tabular}{|c|c|c|c|c|}
\hline \multirow[b]{2}{*}{ Liver } & \multicolumn{2}{|c|}{$\begin{array}{l}\text { Conditions of } \\
\text { present study }\end{array}$} & \multicolumn{2}{|c|}{$\begin{array}{c}\text { Conditions of } \\
\text { Gibson and } \\
\text { associates (34) }\end{array}$} \\
\hline & $\begin{array}{l}\text { Super- } \\
\text { natant }\end{array}$ & $\begin{array}{l}\text { Super- } \\
\text { natant } \\
+ \\
\text { micro- } \\
\text { somes }\end{array}$ & $\begin{array}{l}\text { Super- } \\
\text { natant }\end{array}$ & $\begin{array}{l}\text { Super- } \\
\text { natant } \\
+ \\
\text { micro- } \\
\text { somes }\end{array}$ \\
\hline $\begin{array}{l}\text { Rat } \\
\text { Rat }\end{array}$ & $\begin{array}{l}2.4 \\
9.8\end{array}$ & $\begin{array}{l}12.6 \\
23.4\end{array}$ & $\begin{array}{l}13.1 \\
12.2\end{array}$ & $\begin{array}{r}12.2 \\
6.9\end{array}$ \\
\hline $\begin{array}{l}\text { Human (SA) } \\
\text { Human (AK) }\end{array}$ & $\begin{array}{r}20.5 \\
4.5\end{array}$ & $\begin{array}{l}45.9 \\
17.0\end{array}$ & $\begin{array}{r}12.8 \\
4.2\end{array}$ & $\begin{array}{r}15.0 \\
5.8\end{array}$ \\
\hline
\end{tabular}

* For experimental details see text. Microsomal levels that yielded maximum synthesis were used. Results are expressed as m $\mu$ moles of acetate converted to fatty acids per $\mathrm{mg}$ supernatant protein.

citrate or a tricarboxylic acid metabolically derived from it is obligatory for fatty acid synthesis from acetate in the human (as well as in the rat) supernatant plus microsomal system.

The dependence of fatty acid synthesis in cellfree systems upon the presence of bicarbonate was first demonstrated by Klein in yeast (5), and subsequently in cell-free systems prepared from a variety of animal tissues $(34,35)$. D-Biotin has been shown to be involved in this bicarbonate effect $(6,36)$. Avidin, a protein obtained from egg white, has long been known to bind biotin and render the vitamin ineffective (37). The addition of avidin (Table VI) produced a 90 per cent inhibition of fatty acid synthesis from acetate in the human liver system, and this inhibition was completely reversed by addition of excess D-biotin. Thus, these results demonstrate a $\mathrm{CO}_{2}$-dependence for fatty acid synthesis from acetate in the human liver composite system (supernatant plus microsomes).

According to Wakil, Porter and Gibson (3, 10), fatty acid synthesis in the malonyl-CoA pathway is confined to the supernatant fraction of liver homogenates. Since the cofactor and incubation conditions described by these workers differed from those used here, a comparative study was carried out with the same homogenate in the different media (Table VII). The highest synthesis in our system was obtained by addition of microsomes, whereas in the medium of Gibson, Titchener and Wakil (34), no significant stimulatory effect by microsomes was noted. It is of interest that the supernatant plus microsomal system incubated under our conditions yielded more fatty acids from acetate than did the super-

1)

$\mathrm{CH}_{3}-\stackrel{\mathrm{O}}{\mathrm{C}}-\mathrm{OH}+\mathrm{CoASH} \underset{\text { activation enzyme }}{\stackrel{\mathrm{ATP}, \mathrm{Mg}^{++}\left(\mathrm{Mn}^{++}\right)}{\longrightarrow}} \mathrm{CH}_{3}-\stackrel{\mathrm{O}}{\text { - }}-\mathrm{S}-\mathrm{CoA}$

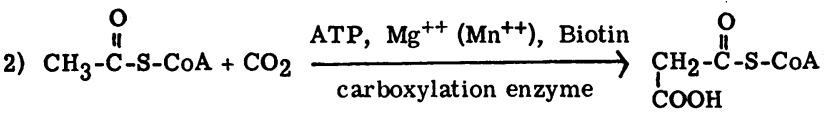

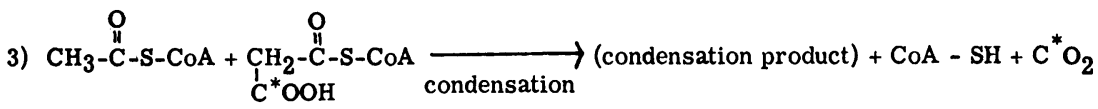

4) (condensation product) $+2 \mathrm{TPNH}+{ }^{2} \mathrm{H}^{+} \underset{\text { reductases }}{\longrightarrow}\left[\mathrm{CH}_{3}-\mathrm{CH}_{2}-\mathrm{CH}_{2}-\stackrel{\mathrm{O}}{\mathrm{C}}-\right]+2 \mathrm{TPN}^{+}+\mathrm{H}_{2} \mathrm{O}$

SUMMATION

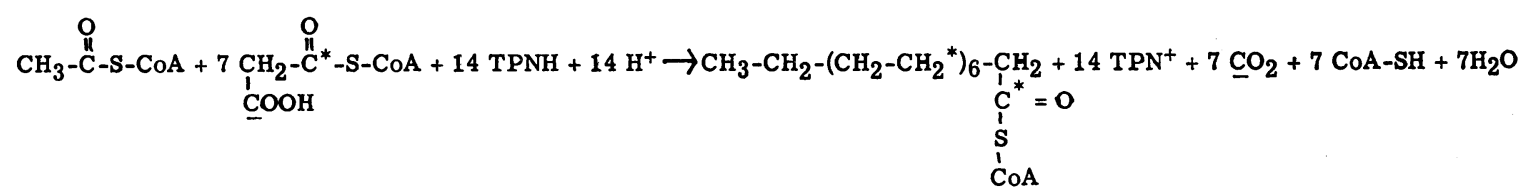

Fig. 3. Pathways of carbon in fatty acid synthesis. 
TABLE VIII

Conversion of the $\mathrm{C}^{14}$ of acetate-1- $\mathrm{C}^{14}$ to $\mathrm{CO}_{2}$, fatty acids, and cholesterol by slices of human and rat liver *

\begin{tabular}{lccc}
\hline & \multicolumn{3}{c}{ Added $\mathrm{C}^{14}$ recovered as: } \\
\cline { 2 - 4 } Liver slices & $\mathrm{CO}_{2}$ & Fatty acids & Cholesterol \\
\hline & $\%$ & $\%$ & $\%$ \\
Human $[5] \dagger$ & $12.4 \pm 0.3$ & $4.0 \pm 1.2$ & $0.5 \pm 0.2$ \\
Rat $[4]$ & $31.4 \pm 1.8$ & $3.3 \pm 1.4$ & $0.7 \pm 0.12$ \\
\hline
\end{tabular}

* For experimental details see text. Average values and their standard errors are given.

† Numbers in brackets indicate number of experiments with different livers. Livers were obtained from Patients $\mathrm{SH}, \mathrm{MI}, \mathrm{AK}, \mathrm{JT}$, and EB

natant fraction incubated under the conditions of Gibson and colleagues (34).

The human liver homogenate system incubated under our specific conditions did not incorporate acetate into nonsaponifiable lipids. The conversion of the $\mathrm{C}^{14}$ of acetate-1-C $\mathrm{C}^{14}$ to $\mathrm{CO}_{2}$, fatty acids, and cholesterol by liver slices is recorded in Table VIII.

\section{DISCUSSION}

The complete synthesis of a long chain fatty acid from acetate in nonmitochondrial systems is the result of a series of reactions (Figure 3 ) in which the initial step involves activation of the acetate to acetyl-CoA. The activation enzyme has been found in the particle-free supernatant fraction obtained from tissue homogenates (34). Early observations with liver slices demonstrated the superiority of a bicarbonate incubation medium for the synthesis of fatty acids (38), and the more recent studies with liver homogenate fractions have left no doubt that bicarbonate is an active participant in the reaction sequence (10, 11). Although an absolute requirement during the reaction, bicarbonate is not incorporated into the final free fatty acid molecule $(6,39)$. The catalytic role of bicarbonate in these reactions has been clarified by Wakil (40), Brady (41), and Lynen (6). Malonyl-CoA (reaction 2, Figure $2)$ has been isolated as a product of the carboxylation of acetyl-CoA $(6,40)$ and its participation in fatty acid synthesis has been demonstrated ( 6 , $40,42)$. It has been suggested that 1 mole of acetyl-CoA and 7 moles of malonyl-CoA are required to form 1 mole of palmitic acid $(10,42$, 43 ), but the specific structure of the condensation products is at present unknown $(44,45)$. It is clear, however, that simultaneous condensation and decarboxylation (removal of the free carboxyl group of malonyl-CoA) are involved, and that these reactions occur before the two reductions that produce a saturated 4-carbon acyl-CoA derivative $(46,47)$. For every 2 -carbon elongation of the chain, 2 moles of hydrogen are needed. Experiments with pyridine nucleotides indicate that TPNH and, to a lesser extent, DPNH can serve as effective hydrogen donors for these reductive steps $(29,48)$. A summary of these reactions is presented in the last line of Figure 3.

Although mitochondria ${ }^{1}$ have been shown to synthesize fatty acids from acetyl-Co.A, the primary function of this particle appears to be concerned with oxidative phosphorylation (49) and fatty acid degradation (50). Therefore, a system devoid of mitochondria would have the advantage of synthesis without concomitant degradative competition. In 1957 Klein (5) described the preparation from yeast of a fatty acid-synthesizing system in which small particles were required for optimal synthesis. Subsequently, we demonstrated that microsomes stimulated lipogenesis in the particle-free supernatant fraction obtained from rat liver homogenates $(12,15)$. This microsomal stimulation has been recently confirmed by Fletcher and Myant (51) in rat liver preparations.

Because of the above considerations, we used the system composed of the supernatant fraction plus microsomes in order to study the mechanism of fatty acid synthesis in human liver and to evaluate the role of peripheral enzymatic reactions upon that synthesis. The enzymatic activities that are not an integral part of the fatty acid synthetic pathway (Figure 3) are retained in such a crude system-an advantage, because the conversion of acetate to fatty acids is dependent upon the products of peripheral reactions that yield $\mathrm{TPNH}$ and $\mathrm{CO}_{2}$. The requirement for TPNH (shown in reaction 4, Figure 3 ) can be satisfied by the presence of glucose-6-phosphate dehydrogenase and gluconic acid-6-phosphate dehydrogenase, isocitric dehydrogenase, or malic enzyme, and their corresponding substrates. The required $\mathrm{CO}_{2}$ (reaction 2) might be supplied by oxidation of a number of substrates, among which are isocitrate, gluconic acid-6-phosphate, and malate. 
In previous experiments with rat liver homogenates (11) we used a medium fortified with cofactors and substrates that yielded a degree of fatty acid synthesis from acetate greater than those observed with liver slices. This same medium was used in the present investigations with human liver. Although it cannot be stated with certainty that the cofactors and substrate levels used in our experiments with the human liver system are optimal, they were, nevertheless, sufficient to provide synthesis higher than that observed with slices.

A microsomal stimulation of fatty acid synthesis from acetate is now also demonstrated in the case of a human liver homogenate system. There appears to be a specific amount of microsomal protein that is optimal for fatty acid synthesis in the human liver system. Addition of larger amounts of microsomes invariably resulted in inhibition of synthesis. ${ }^{8}$ The failure of others (2, 10 ) to observe microsomal stimulation might be explained by the addition of excessive amounts of microsomes. Since, under our incubation conditions, fatty acid synthesis in the composite supernatant plus microsomal system was generally higher than that observed with the incubation conditions of Gibson and co-workers (34), with or without microsomes, the effect of the microsomes cannot be explained solely on the basis of release of an inhibition.

Over 90 per cent of the $\mathrm{C}^{14}$-labeled fatty acids synthesized by the composite (supernatant plus microsomes) human and rat liver systems was found in microsomes isolated from the incubation mixture. This finding led us to consider the possibility that microsomal stimulation of fatty acid synthesis resulted from binding of the newly synthesized fatty acids to these particles. Since we also found that when mitochondria (which do not stimulate fatty acid synthesis in our system) are introduced into the mixture, a great proportion of the fatty acid activity is also bound to them, the stimulatory effect of microsomes is not due solely to removal of fatty acids from the medium (unpublished observation).

\footnotetext{
8 Adenosine triphosphatase was found in microsomal preparations (unpublished observations). Since ATP is required for fatty acid synthesis from acetate, the introduction of excessive levels of adenosine triphosphatase might explain this inhibition.
}

The enzymatic nature of the stimulation by microsomes is indicated by the following observations: 1 ) the presence of an active alpha-beta unsaturated acyl-CoA reducing enzyme (which might catalyze the final reductive step) in the microsomes $(15) ; 2)$ the abolition of the stimulatory effect by denaturation of the protein in the particle (12); and 3) the failure of exhaustive dialysis of the microsomal suspension to decrease the stimulation. It is not at present clear whether the microsomal effect is due to the presence of enzymes directly involved in conversion of acetate to fatty acids or whether it is linked to an enzymic effect of the microsomes upon reactions peripheral to fatty acid synthesis.

Utilization of citrate plays a central role in fatty acid synthesis in both the human and rat systems (14). Other metabolizable tricarboxylic acids produced similar effects. The stimulatory effects of these compounds may be a consequence of the aconitase activity present in the particlefree supernatant fractions of the human and rat liver homogenates, which converts these acids to citrate, or of the action of isocitric dehydrogenase, which produces $\alpha$-ketoglutarate, bicarbonate, and TPNH. As previously noted for rat liver (11) and lactating rat mammary gland (29) preparations, $\alpha$-ketoglutarate plus bicarbonate in the presence of TPNH will not completely substitute for citrate in the human liver system.

As already pointed out, TPNH is required for fatty acid synthesis $(1,10,14,29)$. Although citrate oxidation produces TPNH, its production cannot be the sole factor involved in the citrate effect inasmuch as another TPNH-generating substrate, glucose-6-phosphate, could not be substituted for citrate. The unique role of citrate is further emphasized by the fact that the addition of glucose-6-phosphate plus G-6-PD plus the product of the isocitric dehydrogenase reaction $(\alpha-$ ketoglutarate and bicarbonate) was not so effective in stimulating the conversion of acetate carbon to fatty acids as was citrate.

From the conversion of glucose-6-phosphate-1$\mathrm{C}^{14}$ and citrate-6- $\mathrm{C}^{14}$ to $\mathrm{C}^{14} \mathrm{O}_{2}$ by the supernatant plus microsomal system in human liver, we have calculated (unpublished observations) the production of TPNH from these two substrates under conditions that favor fatty acid synthesis from acetate. The amount of TPNH produced 
by the human liver homogenate system from either substrate is greatly in excess of that theoretically required for the reductive steps involved in the amounts of fatty acid synthesized. Therefore, availability of TPNH from either substrate (glucose-6-phosphate or citrate) cannot be a limiting factor in fatty acid synthesis by the human liver system.

\section{SUM MARY}

1. Homogenates of human liver were separated into mitochondrial, microsomal, and particle-free supernatant fractions. These fractions were incubated in a medium fortified with cofactors and oxidizable substrates, and their capacities to synthesize fatty acids from acetate were studied.

2. A stimulatory effect of microsomes upon the conversion of acetate carbon to fatty acids by the particle-free, supernatant fraction isolated from human liver was demonstrated. Addition of microsomes beyond a certain level resulted, however, in inhibition of the fatty acid synthesis.

3. The addition of either citrate, isocitrate, or aconitate, in addition to TPNH, was an obligatory requirement in order to obtain high levels of fatty acid synthesis in the human composite system (supernatant fraction plus microsomes). Glucose-6-phosphate failed to serve as a substitute for this citrate requirement, as also did a combination of glucose-6-phosphate, glucose-6-phosphate dehydrogenase, $\mathrm{CO}_{2}$, and $\alpha$-ketoglutarate.

4. As shown previously in rat liver, TPNH generation does not limit fatty acid synthesis from acetate by the human liver composite system.

5. The participation of $\mathrm{CO}_{2}$ in the conversion of acetate carbon to fatty acids by human liver is suggested by the demonstration of an avidin inhibition which was reversed by the addition of biotin.

\section{REFERENCES}

1. Langdon, R. G. The requirment of triphosphopyridine nucleotide in fatty acid synthesis. J. Amer. chem. Soc. 1955, 77, 5190.

2. Langdon, R. G. The biosynthesis of fatty acids in rat liver. J. biol. Chem. 1957, 226, 615.

3. Wakil, S. J., Porter, J. W., and Gibson, D. M. Studies on the mechanism of fatty acid synthesis. I. Preparation and purification of an enzyme system for reconstruction of fatty acid synthesis. Biochim. biophys. Acta 1957, 24, 453.

4. Brady, R. O., Mamoon, A. M., and Stadtman, E. R. The effects of citrate and coenzyme $A$ on fatty acid metabolism. J. biol. Chem. 1956, 222, 795.
5. Klein, H. P. Some observations on a cell free lipid synthesizing system from Saccharomyces cerevisiae. J. Bact. 1957, 73, 530.

6. Lynen, F. Participation of acyl-CoA in carbon chain biosynthesis. J. cell. comp. Physiol. 1959, 54, suppl. 1, 33.

7. Kusunose, E., Kusunose, M., Kowa, Y., and Yamamura, Y. The synthesis of fatty acids in the cellfree extract of Mycobacterium avium. J. Biochem. (Tokyo) 1960, 47, 689.

8. Vagelos, P. R. Caproyl coenzyme A dependent malonyl coenzyme A-bicarbonate exchange reaction. J. Amer. chem. Soc. 1959, 81, 4119.

9. Wakil, S. J., McLain, L. W., Jr., and Warshaw, J. B. Synthesis of fatty acids by mitochondria. J. biol. Chem. 1960, 235, PC 31.

10. Wakil, S. J. Mechanism of fatty acid synthesis. J. Lip. Res. 1961, $2,1$.

11. Abraham, S., Matthes, K. J., and Chaikoff, I. L. Fatty acid synthesis from acetate by normal and diabetic rat liver homogenate fractions. I. A comparison of cofactor requirements. J. biol. Chem. 1960, 235, 2551.

12. Matthes, K. J., Abraham, S., and Chaikoff, I. L. Fatty acid synthesis from acetate by normal and diabetic rat liver homogenate fractions. II. Effect of microsomes and oxidation of substrates. J. biol. Chem. 1960, 235, 2560.

13. Abraham, S., Matthes, K. J., and Chaikoff, I. L. Role of TPNH in fatty acid synthesis from acetate by normal and diabetic rat-liver homogenate fractions. Biochim. biophys. Acta 1959, 36, 556.

14. Abraham, S., Matthes, K. J., and Chaikoff, I. L. Relation of citrate oxidation to fatty acid synthesis in liver and lactating mammary gland. Biochem. biophys. Res. Com. 1960, 3, 646.

15. Matthes, K. J., Abraham, S., and Chaikoff, I. L. An enzymic defect in fatty acid synthesis by alloxandiabetic rat liver. Biochim. biophys. Acta 1960, 37, 180.

16. Lipsky, S. R., Haavik, A., Hopper, C. L., and McDivitt, R. W. The biosynthesis of the fatty acids of the plasma of man. I. The formation of certain chromatographically separated higher fatty acids of the major lipide complexes from acetate-1- $\mathrm{C}^{14}$. J. clin. Invest. 1957, 36, 233.

17. Hennes, A. R., and Shreeve, W. W. Hormonal effects on $\mathrm{C}^{14}$ acetate metabolism in the human. Proc. Soc. exp. Biol. (N. Y.) 1959, 100, 246.

18. Hennes, A. R., and Redding, T. W. Defective synthesis of triglyceride fatty acids from $1-\mathrm{C}^{14}$ acetate in the well controlled stable adult diabetic. Diabetes 1961, 10, 85 .

19. Hosoya, N., Hagerman, D., and Villee, C. Stimulation of fatty acid synthesis by oestradiol in vitro. Biochem. J. 1960, 76, 297.

20. Rabinowitz, J. L. Fat deposition and fat biogenesis in the human aorta. Fed. Proc. 1961, 20, 273. 
21. Seubert, W., Greull, G., and Lynen, F. Die synthese der fettsäuren mit gereininigten enzymen des fettsäurecyclus. Angew. Chem. 1957, 69, 359.

22. Tietz, A. Studies on the mechanism of fatty acid synthesis. IV. Biosynthesis of long-chain fatty acids in a reconstructed system of soluble enzymes from chicken liver. Biochim. biophys. Acta 1957, 25, 303.

23. Langdon, R. G. Hormonal regulation of fatty acid metabolism in Lipid Metabolism, K. Bloch, Ed. New York, John Wiley, 1960, p. 255.

24. McIlwain, H., and Buddle, H. L. Techniques in tissue metabolism: 1. A mechanical chopper. Biochem. J. 1953, 53, 412.

25. Baruch, H., and Chaikoff, I. L. A simpliefid method for determination of lipide- $\mathrm{C}^{\mathbf{1 4}}$ in liver. Proc. Soc. exp. Biol. (N. Y.) 1954, 86, 97.

26. Calvin, M., Heidelberger, C., Reid, J. C., Tolbert, B. M., and Yankwich, P. F. Synthesis of carbonlabeled compounds in Isotopic Carbon: Techniques in its Measurement and Chemical Manipulation, M. Calvin and others. New York, John Wiley, 1949, p. 148.

27. Vickery, H. B., and Wilson, D. G. Potassium dihydrogen $\mathrm{L}_{\mathbf{s}}(+)$ isocitrate in Biochemical Preparations, H. A. Lardy, Ed. New York, John Wiley, 1960, vol. 7, p. 72.

28. Deutsch, D. H., and Phillips, R. E. Preparation of tricarboxylic acids in Methods in Enzymology, S. P. Colowick and N. O. Kaplan, Eds. New York, Academic Press, 1957, vol. 3, p. 421.

29. Abraham, S., Matthes, K. J., and Chaikoff, I. L. Factors involved in synthesis of fatty acids from acetate by a soluble fraction obtained from lactating rat mammary gland. Biochim. biophys. Acta 1961, 49, 268.

30. Hotta, S., Hill, R., and Chaikoff, I. L. Mechanism of increased hepatic cholesterogenesis in diabetes: Its relation to carbohydrate utilization. J. biol. Chem. 1954, 206, 835.

31. Abraham, S., and Hassid, W. Z. The synthesis and degradation of isotopically labeled carbohydrates and carbohydrate intermediates in Methods in Enzymology, S. P. Colowick and N. O. Kaplan, Eds. New York, Academic Press, 1957, vol. 4, p. 489.

32. Gornall, A. G., Bardawill, C. J., and David, M. M. Determination of serum proteins by means of the biuret reaction. J. biol. Chem. 1949, 177, 751.

33. Horecker, B. L., and Kornberg, A. The extinction coefficients of the reduced band of pyridine nucleotides. J. biol. Chem. 1948, 175, 385.

34. Gibson, D. M., Titchener, E. B., and Wakil, S. J. Studies on the mechanism of fatty acid synthesis. $\mathrm{V}$. Bicarbonate requirement for the synthesis of long-chain fatty acids. Biochim. biophys. Acta 1958, 30, 376.

35. Abraham, S., Matthes, K. J., and Chaikoff, I. L. Effect of biotin and avidin on conversion of acetate to fatty acids and acetoacetate by preparations from rat liver and lactating rat mammary gland. Biochim. biophys. Acta 1961, 46, 197.

36. Wakil, S. J., and Gibson, D. M. Studies on the mechanism of fatty acid synthesis. VIII. The participation of protein-bound biotin in the biosynthesis of fatty acids. Biochim. biophys. Acta 1960, $41,122$.

37. Gyorgy, P. Biotin. II. Chemistry in The Vitamins, W. H. Sebrell, Jr. and R. S. Harris, Eds. New York, Academic Press, 1954, 1, p. 555.

38. Brady, R. O., and Gurin, S. The biosynthesis of radioactive fatty acids and cholesterol. J. biol. Chem. 1950, 186, 461.

39. Gibson, D. M., Titchener, E. B., and Wakil, S. J. Requirement for bicarbonate in fatty acid synthesis. J. Amer. chem. Soc. 1958, 80, 2908.

40. Wakil, S. J. A malonic acid derivative as an intermediate in fatty acid synthesis. J. Amer. chem. Soc. 1958, 80, 6465 .

41. Brady, R. O. The enzymatic synthesis of fatty acids by aldol condensation. Proc. nat. Acad. Sci. (Wash.) 1958, 44, 993.

42. Martin, D. B., Horning, M. G., and Vagelos, P. R. Fatty acid synthesis in adipose tissue. I. Purification and properties of a long chain fatty acidsynthesizing system. J. biol. Chem. 1961, 236, 663.

43. Brady, R. O., Bradley, R. M., and Trams, E. G. Biosynthesis of fatty acids. I. Studies with enzymes obtained from liver. J. biol. Chem. 1960, 235, 3093.

44. Bressler, R., and Wakil, S. J. Studies on the mechanism of fatty acid synthesis. IX. The conversion of malonyl coenzyme $A$ to long chain fatty acids. J. biol. Chem. 1961, 236, 1643.

45. Lynen, F. Enzymes and cofactors involved in fatty acid synthesis. Colloques Inter. Centre nat. Recherche sci. 1961, 99, 71.

46. Vagelos, P. R., and Alberts, A. W. Malonyl coenzyme $\mathrm{A}-\mathrm{CO}_{2}$ exchange reaction. J. biol. Chem. 1960, 235, 2786.

47. Pujari, H. K. Acetyl CoA and malonyl CoA condensation by the fatty acid synthesizing system. Fed. Proc. 1961, 20, 274.

48. Wakil, S. J., Titchener, E. B., and Gibson, D. M. Studies on the mechanism of fatty acid synthesis. VI. Spectrophotometric assay and stoichiometry of fatty acid synthesis. Biochim. biophys. Acta 1959, 34, 227.

49. Green, D. E., and Beinert, H. Biologic oxidations. Ann. Rev. Biochem. 1955, 24, 1.

50. Kennedy, E. P., and Lehninger, A. L. Oxidation of fatty acids and tricarboxylic acid cycle intermediates by isolated rat liver mitochondria. J. biol. Chem. 1949, 179, 957.

51. Fletcher, K., and Myant, N. B. The effect of some cofactors on the synthesis of fatty acids and cholesterol in cell-free preparations of rat liver. J. Physiol. (Lond.) 1961, 155, 498. 